\title{
ROLE OF PLANNING AND BUDGET TO THE DEVELOPMENT OF AGROPOLITAN AREA
}

\author{
Sirojuzilam \\ Accounting Department of Economic \&Bussiness Faculty \\ Universitas Sumatera Utara \\ sirojuzilam@usu.ac.id
}

Iskandar Muda

\author{
Accounting Department of Economic \&Bussiness Faculty \\ Universitas Sumatera Utara \\ iskandar1@usu.ac.id
}

\author{
Syahrir Hakim \\ Accounting Department of Economic \&Bussiness Faculty \\ Universitas Sumatera Utara \\ syahrirhakim@usu.ac.id
}

\begin{abstract}
The purpose of this research is to know the role of planning and budget of Regency around Agropolitan Area to Agropolitan Bukit Barisan area development. This type of research is explanatory survey. This research is conducted by conducting primary data survey from aspect of planning and budget of Regency to around Agropolitan Area. The results show the weakness of planning influence to the development of Agropolitan Bukit Barisan area and the lack of budget not influence the development of Agropolitan Bukit Barisan area.
\end{abstract}

Keywords:planning, budget allocation, Agropolitan,
development.

\section{INTRODUCTION}

The causal-link concepts contained in the chain of results are not fully considered and or are not sufficiently understood. As a result, planning formats are not coherently and systematically contained where there is often an illogical relationship between expected impacts with goals/objectives and with outcomes and outputs as a means to achieve the desired impact. Issues get more complex when linked with the determination of indicators [1]. In addition to being systematically unstructured, indicators emblazoned in most planning documents do not have measurable targets. The inequality of perception of the concept of the indicator itself in the circle's planners in the region, scarcity of measurable indicators and other eligibility in such planning documents are due to excessive concerns that the indicator is a boomerang, if not achieved. Other fundamental issues which partly involve the instrumental method, is the difficulty of synchronization and or increase synergies of inter-sector strategy and programs, although the region already has a vision, mission and policy direction. This requires understanding the model of the structural relationship of objectives, objectives, and outcomes RPJMD with goals, objectives and sectoral outcomes. Revitalization of long-term development planning as set out in [37] is one important approach to support sustainability of national development and can promote effectiveness and efficiency through synchronization and enhanced program synergies between the center and the region as well cross-sectoraldevelopment programs in the regions. After all, in social and political conditions the domestic market as well as the rapidly changing and full global strategic environment challenges, the existence of vision, strategic mission and medium-term political contract intermediate between the executive and the legislature in the form of a medium-term budget framework is very important.The taker's policies and planners in the regions seem to be faced with reference issues because there are things that are not aligned with [36] with [37]. Concretely, the approach of Law Number 17/2003 does not recognize program synchronization and cross-sectoral activities before the draft budget is brought to the legislative, while at other parties of expressly state that program synchronizationis the most important aspect before the budget is set. Furthermore, mentions the need for a medium-term expenditure framework, the articles governing the process of drafting and APBD's determination in the Act seems to be still caught in focus short-term, i.e. annual budget mechanism and process-APBD. Constitutiononly slightly offends the planning dimension, so it cannotbridge the isolation between planning and budgeting.

Agropolitan consists of the agriculture and the word Politan so that agropolitan can be interpreted as an agricultural city that grows and develops due to the running of agribusiness systems and business and able to serve, encourage, attract, push agricultural development activities in the surrounding area[2]. Bukit Barisan Highland of North Sumatra which is an area of Agropolitanwhich consists of 9 regencies/cities in North Sumatra. This program started from the 5 Regent's Memorandum of Understanding on 28 September 2002 on the establishment of Agropolitan Area Development.The development of agropolitan areas is a strategy that is necessary, not only because of the imbalance between rural and urban areas but also because of the high 
potential available in rural areas that can be utilized to encourage developmental coherence.

The development of agropoiitan area becomes very important in the context of regional development considering the area and sectors developed are locally specific, the development of agropolitan area can increase the production and income of the community, besides the selected sector is the basis of community activity[19] \&[33]. The sustainability of regional and sector development is more certain given that the selected sector has a competitive and comparative advantage compared to other sectors[1], [3], [4], [9] \& [10].Commodities can be an economic driver in the countryside. In agricultural areas that will be used as agropolitan areas, while the commodities demanded by the market will provide a high multiplier effect that can become an economic driver for the community.If in one area there are more than one commodity is expected to be realized one-village one commodity program.

\section{METHOD}

This study usessecondarydata.The data were obtained from Central Bureau of Statistics. North Sumatera In Figures in the period 2000-2015. The hypothesis was tested by using Structural Equation Modeling (SEM) with SMART PLS software. The data analysis technique in this research employed. SEM is a set of statistical techniques allowing testing of a series of relationships simultaneously. Furthermore, in the data processing, the writer used the aid from software SMART-PLS Structural Equation Modeling, which was one of the multivariate analyses capable of analyzing the variable relationships in complex manner [30]. The hypotheses were tested using Structural Equation Modeling (SEM) with Smart-PLS software tools. The equation is formed as follows:

$$
\mathbf{Y}=\alpha+\mathbf{b}_{1} \mathbf{X}_{1}+\mathbf{b}_{2} \mathbf{X}_{2}+\mathbf{e}
$$

$$
\begin{array}{ll}
\mathrm{X}_{1} & =\text { Planning } \\
\mathrm{X}_{2} & =\text { Budget Allocation } \\
\mathrm{Y} & =\text { Agropolitan Development } \\
\mathrm{b}_{1, \ldots \mathrm{b}_{3}} & =\text { Coefficient } \\
\alpha & =\text { Constant } \\
\mathrm{e} & =\text { Error }
\end{array}
$$

This phase is done to test the suitability of the model to evaluate the goodness-of-fit index. Analysis using SEM requires some suitability index to measure the correctness of data and models.

\section{RESULT}

A. Result

1. Evaluation of Structural Model (Inner Model)

Inner model evaluation through the bootstrapping menu also generates $\mathrm{T}$-statistics values that will be used to test the hypothesis. The criteria are T-statistic> 1.66 [40]. The result of T-statistics value in the table path coefficients is presented in the following figure:

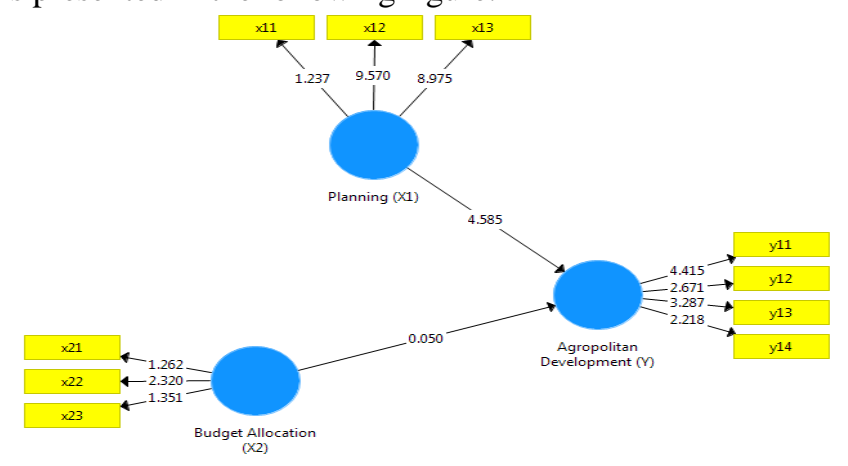

Figure 4.Overall Model with Coefficient

The effect test can be seen in the following table:

Table 2. The result of bootstrapping

\begin{tabular}{lccccc}
\hline & $\begin{array}{c}\text { Original } \\
\text { Sample (O) }\end{array}$ & $\begin{array}{c}\text { Sample } \\
\text { Mean } \\
(\mathrm{M})\end{array}$ & $\begin{array}{c}\text { Standard } \\
\text { Deviation }\end{array}$ & $\begin{array}{c}\text { T } \\
\text { Statistics }\end{array}$ & P Values \\
\hline $\begin{array}{l}\text { Budget Allocation (X2) - } \\
\text { >Agropolitan Development (Y) }\end{array}$ & $-0,008$ & 0,092 & 0,159 & 0,050 & 0,960 \\
\hline $\begin{array}{l}\text { Planning (X1) -> Agropolitan } \\
\text { Development (Y) }\end{array}$ & 0,527 & 0,490 & 0,115 & 4,585 & 0,000 \\
\hline
\end{tabular}

Source: PLS Output (2017). affect Agropolitan Development.

The results show that Planning variable affects Agropolitan Development. While the Budget Allocation variable does not 


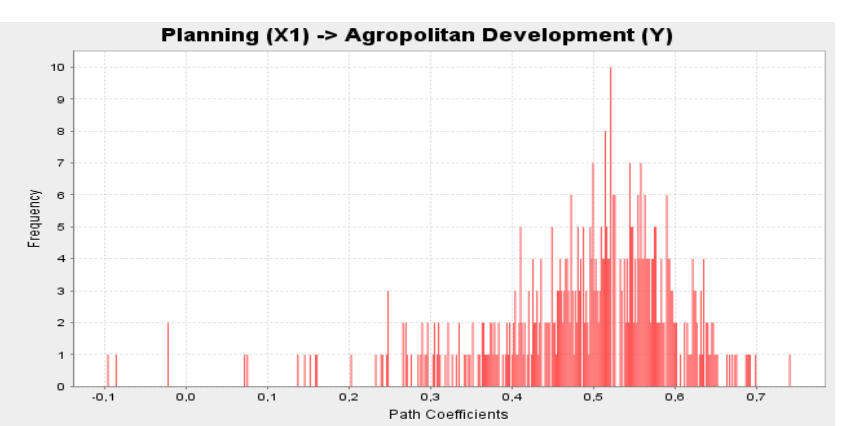

Source: PLS Output (2017).

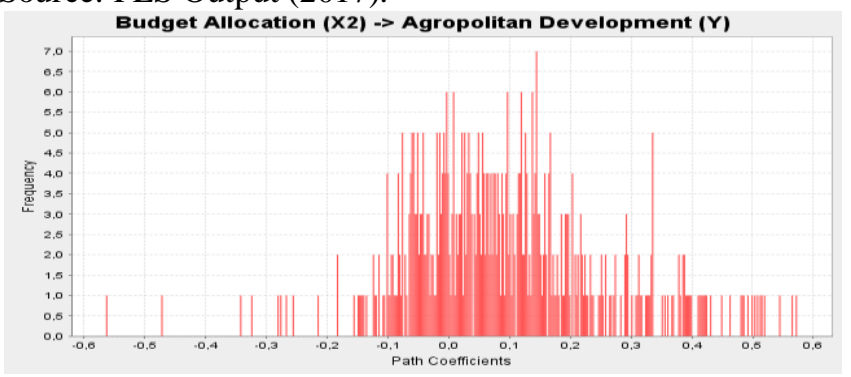

Source: PLS Output (2017).

Based on the above table the indirect effect produces coefficient of 0.005 , smaller than $1.66(\alpha=5 \%)$ then the decision of hypothesis testing reject $\mathrm{HO}$ and accept the hypothesis Ha [5], [11], [12] \& [13].In addition to hypothesis testing through the bootstrapping menu that produces T-statistics, inner model evaluation is also done by reviewing the R-Square value [5], [16], [17], [18], [24] \& [25]. The R-square value generated from the inner model evaluation is presented in the following table:

Table 3.Confidence Intervals

\begin{tabular}{|c|c|c|c|}
\hline & $\begin{array}{c}\text { Original } \\
\text { Sample }(\mathrm{O})\end{array}$ & $\begin{array}{l}\text { Sample } \\
\text { Mean } \\
(\mathrm{M})\end{array}$ & $\begin{array}{l}\text { IV. CONCLUSIONS } \\
2 \text { Th\% resubts. } 5 \text { bow the weakness of planning influence to the } \\
\text { development ofAgropolitan Bukit Barisan area and the lack }\end{array}$ \\
\hline $\begin{array}{l}\text { Budget Allocation (X2) - } \\
\text { >Agropolitan Development (Y) }\end{array}$ & 0,000 & 0,044 & 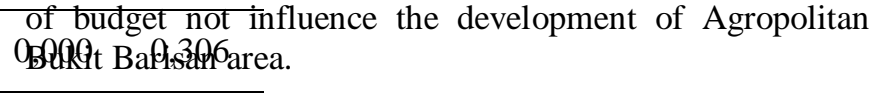 \\
\hline
\end{tabular}

\begin{tabular}{lllll}
\hline $\begin{array}{l}\text { Planning (X1) ->Agropolitan } \\
\text { Development (Y) }\end{array}$ & 0,329 & 0,318 & 0,063 & 0,590
\end{tabular}

Source: PLS Output. (2017).

Although [36] cites the need for a medium-term expenditure framework, the articles governing the process of drafting and determining the APBD in the Act seem to be still trapped in the short-term focus. Under current conditions of political and socio-economic dynamism as experienced by Indonesia today and the rapidly changing global-regional strategic environment, medium-term planning is merely indicative; but without an instrument and a binding medium-term budget policy commitment executives and legislatures, the annual budget discussion will still be easily trapped into a venue of interest attraction that ultimately results in a budget decision not realistic and or not right target [28], [29], [32] \& [33]. Therefore, the Government Regulation will issue should describe more detailed concepts and provisions concerning the framework the medium term budget [6], [7] \& [8]. However, without any strategic and framework medium-term programs that contain specific objectives, outcomes, and outputs and has a measurable target, it is impossible to develop a mediumterm budget framework and performance budgets [20],[21], [22], [23], [26] \& [27] .

In line with the above perspective, regional planning for the long and medium-term needs to integrate the various document products coherently covering spatial planning, and regional poverty reduction strategies [34], [35]. Otherwise, the Regional Spatial Plan should be an integral element of the Regional Medium Term Plan Document. Coherent ordering is necessary to familiarize the use of systematic instruments and structures such as the Agropolitan Program. Trends so far indicate that the Spatial Plan in Bukit Barisan Sumatera Utara tends to be forgotten in the annual budgeting. Furthermore, substantially there needs to be a reorientation of the spatial document to be a means of alleviating poverty and in line with sustainable development programs[36], [37], [38] \& [39]. The condition of the agropolitan area varies from region to region. There are various factors that affect the speed of the development of the area, including human resource conditions, climate, market demand and others [10], [14],[15],[31] \&[32]. Complete information and a good understanding of the various factors that support or hinder the success of the program will be very helpful in order to prepare for future improvement measures. Therefore, this assessment is directed to see the application of the concept of agropolitan area in some areas which since a few years ago has been declared as the location of agropolitan area development by each district/city government.

\section{CONCLUSIONS}

\section{References}

[1]. Agusta, I. "Paradigmatic leap of agropolitan program in Indonesia: From the paradigm of human-based development to the modernization paradigm". Policy Paper SKPM, Vol.1 Issue 1. (2012). pp.18-31.

[2]. Azlina, Nur., Amir Hasan, Desmiyawati\&Muda, I. "The Effectiveness of Village Fund Management (Case Study at Villages in Coastal Areas in Riau)". International Journal of Economic Research. Vol.14 Issue 12. (2017). pp.325-336.

[3]. Basuki, Agus Tri. "Agropolitan Area Development". Journal of Economics and Development Studies. Vol.13. Issue 1. (2012). pp.53-71.

[4]. Carel, P., \&Schoeman, B. "Transportation planning and its interface with spatial planning and environmental management: the position within South Africa”. Urban Transport XVII: Urban Transport and the Environment in the 21st Century, Vol.116(2011), 155.

[5]. Dalimunthe., D.M.J.,Fadli, and Muda, I. "The application of performance measurement system model using Malcolm Baldrige Model (MBM) to support Civil State Apparatus Law (ASN) number 5 of 2014 in Indonesia". International Journal of Applied Business and Economic Research. Vol.14 Issue 11. (2016). pp.7397-7407. 
[6]. Erlina., Ari Saputra\&Muda, I. "Antecedents of Budget Quality Empirical Evidence from Provincial Government In Indonesia". International Journal of Economic Research. Vol. 14 Issue 12. (2017). pp.301-312.

[7]. Erlina., Ari Saputra\&Muda, I. "The Analysis of the Influencing Factors of Budget Absorption". International Journal of Economic Research. Vol. 14 Issue 12. (2017). pp.287-300.

[8]. Erlina.,"ConflictofInterestImpact:

FactorsAnalysisAffectingtheBudgetQualityinMedanCity". International Journal of Economic Research.Vol.14 Issue 12. (2017). pp.135-145.

[9]. Fatkhiati, S., Tjiptoherijanto, P., Rustiadi, E., \&Thayib, M. H.."Sustainable agropolitan management model in the highland of tropical rainforest ecosystem: the case of SelupuRejangagropolitan area, Indonesia”. Procedia Environmental Sciences, Vol.28 Issue 1.(2015). pp.613-622.

[10]. Gable, C. Strategic action planning, Now: 4 guide for setting and meeting your goals.St. Lucie Press. London. (2012).

[11]. Gusnardi.,Riadi, R.M., and Muda, I. "Competency mapping, and analysis of students competency based on economics subject national examination and its alternative solutions in state high schools at Pekanbaru". International Journal of Economic Research. Vol.3 Issue 5. (2016). pp.2133-2148.

[12]. Handoko, Bagus.,Sunaryo\&Muda, I. "Difference Analysis of Consumer Perception of Motorcycle Product Quality". International Journal of Economic Research. Vol. 14 Issue 12. (2017). pp.363-379.

[13]. Hasan., Amir, Gusnardi\&Muda, I. "Analysis of Taxpayers and Understanding Awareness Increase in Compliance with Taxpayers Individual Taxpayers". International Journal of Economic Research. Vol.14 Issue 12. (2017). pp. 75-90.

[14]. Hastuti, H. I. "Model of Area Development with Agropolitan Approach (Case Study Banjarnegara District", Central Java Province). (2001).

[15]. Lindgren, M., H. Banhold. "Scenario planning: The link between future and strategy" (2003).New York. Palgrave Macmillan.

[16]. Lubis., A.,Torong, Z.B., and Muda, I. The urgency of implementing balanced scorecard system on local government in North Sumatra - Indonesia. International Journal of Applied Business and Economic Research. Vol.14 Issue 11. (2016). pp.7575-7590.

[17]. Lubis., A.F., Lubis, T.A., and Muda, I. "The role of Enterprise Resource Plan (ERP) configuration to the timeliness of the financial statement presentation". International Journal of Applied Business and Economic Research. Vol.14 Issue 11. (2016). pp.7591-7608.

[18]. Lutfi., M.,Nazwar, C., and Muda, I "Effects of investment opportunity set, company size and real activity manipulation of issuers in Indonesia Stock Exchange on stock price in Indonesia". International Journal of Economic Research. Vol.13 Issue 5. (2016). pp.2149-2161.

[19]. Mazdalifa, A. F. "Implementation of Agropolitan Area Development Policy InLamongan District”. Journal of Public Administration, Vol.1 Issue 3, (2013). pp. 18-26.

[20]. Muda., I and AbykusnoDharsuky. "Impact of Region Financial Information System (SIKD) Quality, Role Ambiguity And Training on Precision of Financial Statement of Local Government Presentation In North Sumatra". International Journal of Applied Business and Economic Research, Vol.13 Issue 6. (2015). pp.4283-4304.

[21]. Muda., I, DeniYuwiliaWardani, Erlina, AzharMaksum, Ade FatmaLubis and Rina Bukit. "The Influence of Human Resources Competency and The Use of Information Technology on The Quality of Local Government Financial Report with Regional Accounting System as an Intervening". Journal of Theoretical and Applied Information Technology. Vol.95 Issue 17. (2017). pp.1432-1451.

[22]. Muda., I, Dharsuky. A., Siregar, H.S., and Sadalia, I. "combined loading and Cross-dimensional loadings timeliness of presentation of financial statements of local government". IOP Conference Series : Materials Science and Engineering.
Bandung, (2017). 180. doi: 10.1088/1757899X/180/1/012099.

[23]. Muda., I, Marlon Sihombing, ErniJumilawati and AbikusnoDharsuky. "Critical Success Factors Downstream Palm Oil Based Small And Medium Enterprises (SME) In Indonesia". International Journal of Economic Research. Vol.13 Issue 8. (2016). pp. 3531-3538.

[24]. Muda., I., Rafiki, A., \&Harahap, M. R. "Factors Influencing Employees' Performance: A Study on the Islamic Banks in Indonesia". International Journal of Business and Social Science, Vol.5Issue 2. (2014). pp. 73-80.

[25]. Muda., I.,Dharsuky, A.,Sadalia, I., and Siregar, H.S. "Impact of capital investments and cash dividend policy on Regional Development Bank (BPD) PT. Bank Sumut to the district own source revenue and economic growth". International Journal of Applied Business and Economic Research. Vol.14 Issue 11. (2016). pp.7863-7880.

[26]. Muda.,Iskandar. "The Effect of Supervisory Board CrossMembership and Supervisory Board Members' Expertise to The Disclosure of Supervisory Board's Report: Empirical Evidence From Indonesia". European Research Studies Journal. Vol.XX Issue 3A. (2017). pp.702-716.

[27]. Nasir, Azwir.,YesiMutiaBasri, Kamaliah\&Muda, I. "Effectiveness of Potential Tax Region as the Real Local Revenue Sources in Riau Coastal Area”. International Journal of Economic Research. Vol.14 Issue 12. (2017). pp.313-324.

[28]. Oktavia, S. "The Relationship between Role of the Stakeholders and Community participation in Agropolitan Program in Karacak Village, LeuwiliangSubdistrict, Bogor" District. Sodality: JurnalSosiologiPedesaan, Vol.1Issue 3. (2015). pp.17-29.

[29]. Rustiadi, E., \&Dardak, E. E. Agropolitan(Strategy for Development of Growth Center in Rural Area).(2008). Crestpent Press.

[30]. Sadalia, .Isfenti., Nur Ahmadi Bi Rahamani\&Muda, I. "The Significance of Internet-Based Financial Information Disclosure on Corporates' Shares in Indonesia”. International Journal of Economic Research. Vol.14 Issue 12. (2017). pp.337-346.

[31]. Sintaningrum\&TomiSetiawan. "Quo Vadis Policy of Agropolitan Area in Indonesia ?".Journal of Public Service Management. Vol.1 Issue 1. (2017). pp.88-102.

[32]. Tomlinson, R..."Planning local economic development: Theory and practice, By Edward J Blakely, Sage Publications, Newbury Park, 1989”. Development Southern Africa, Vol.7Issue 4.(1990). 743-750.

[33]. Wantu, S. M., \&Moonti, U. Corn.“Agropolitan for Great Gorontalo Indonesia". Research Journal of Applied Sciences, Vol.11Issue 9, (2016). 866-869.

[34]. Yahya.,Idhar., Torong, Z.B., and Muda, I.. "Influence Behavior in Legislature Budget Development of Regions in the Province of Aceh and North Sumatra". International Journal of Economic Research, Vol.14 Issue 8. (2017). pp. 147-159.

[35]. Yunitasari, A. "The Role of Local Governments in Local Economic Development ThroughAgropolitan Agricultural Sector (Study on Local Development Planning Agency (BAPPEDA) and Batu Forestry and Agriculture Office)."Journal of Public Administration, Vol.1 Issue 10. (2013). pp.25-38

[36]. The government of the Republic of Indonesia. (2003). Law of the Republic of Indonesia Number 17 Year 2003 on state finance. Jakarta.

[37]. ___ (2004). Law of the Republic of Indonesia Number 25 Year 2004 regarding the system national development planning. Jakarta.

[38]. __ (2004). Law of the Republic of Indonesia Number 32 Year 2004 regarding local government. Jakarta.

[39]. __ (2004). Law of the Republic of Indonesia Number 33 Year 2004 regarding the financial balance between central and regional governments. Jakarta.

[40]. Sirojuzilam, Hakim, S., and Muda, I. "Effect of Private Collaborative as a Moderation of Success of Agropolitan 
Program". International Journal of Economic Research. (2017).Vol.14 No.16. pp.304-315. 